\title{
Towards legal pragmatism: breach of confidence and the right to privacy
}

\author{
MEGAN RICHARDSON*
}

\section{A. Introduction}

In How Fiction Works, ${ }^{1}$ literary critic James Wood compares literary fiction with moral philosophy. As Wood explains, while fiction and especially novels are concerned with the reality of human existence, there is a certain persuasive criticism of much modern moral philosophy that it 'essentially wrote the messiness of the self out of moral discussion'. ${ }^{2}$ The critique is shared by philosopher Bernard Williams who argues that modern Kantian philosophers tend to view moral dilemmas as easily solved by identifying then elevating the correct 'universal' moral principle while in reality life may involve more than one possible moral stance and people who respond differently to moral choices, their decisions influenced by a range of factors - genetics, upbringing, society and so on. ${ }^{3}$ Similarly, philosopher and law academic Cass Sunstein notes that: ${ }^{4}$

The hard question, not yet fully elaborated in the philosophical literature, remains: How does one make choices in cases in which incommensurable social goods are at stake, and in which some of these goods must be sacrificed?

\footnotetext{
- With grateful thanks to Michael Bryan whose deep knowledge of breach of confidence and generosity in sharing his work and ideas with others has inspired me, to the editors for embarking on and carrying through this most worthy project, and to Peiwen Chen for her excellent research assistance. Since breach of confidence/privacy law is a rapidly moving field, it should be noted that this essay reflects developments as at October 2009.

1 J Wood, How Fiction Works (Jonathan Cape, London 2008).

2 Ibid 133.

${ }^{3}$ See for instance, B Williams, Ethics and the Limits of Philosophy (Routledge, London 1985) and AW Moore (ed), Bernard Williams: Philosophy as a Humanist Discipline (Princeton University Press, Princeton 2006).

${ }^{4}$ C Sunstein, 'On Analogical Reasoning' (1993) 106 Harv L Rev 788.
} 
As Sunstein points out, in Anglo-American jurisprudence the judge's traditional response to such problems is to avoid confronting them head on, adopting instead a process of incremental reasoning in which previous decisions of judges on like questions a re taken as the starting point for resolving the case at hand, the focus is on the particulars of disputes, and legal positions are incompletely theorized in advance.

In Australia, incrementalism has also been identified as the preferred legal method. Thus in Australian Broadcasting Corporation $v$ Lenah Game Meats Pty Ltd, ${ }^{5}$ faced with an argument that the High Court should recognize a new privacy cause of action extending to scenes of possums being stunned and killed in a game meat abattoir, Gummow and Hayne JJ respond as follows: ${ }^{6}$

In the present appeal, Lenah encountered ... difficulty in formulating with acceptable specificity the ingredients of any general wrong of unjustified invasion of privacy. Rather than a search to identify the ingredients of a generally expressed wrong, the better course ... is to look to the development and adaptation of recognised forms of action to meet new situations and circumstances.

Some scholars and judges have argued that 'top-down' styles of reasoning offer better prospects of effective decision-making in the common law.? But 'bottom-up' reasoning has certain utilitarian advantages. In a classic article on 'The Science of "Muddling Through"', , economist Charles Lindblom observes that, not only is incrementalism the normal approach to administrative decision-making, its reliance on marginal analysis and its focus on results rather than theory reflect a more genuinely pragmatic approach to problem-solving than the alternative 'rational-comprehensive' method. In particular, 9

The idea that values should be clarified, and in advance of examination of alternative policies, is appealing. But what happens when we attempt it for complex social problems? The first difficulty is that on many critical values or objectives, citizens disagree, congressmen disagree, and public administrators disagree ... Even if all administrators had at hand an

5 (2001) 208 CLR 199 ('Lenah'). 6 Ibid [110].

7 For instance, R Posner, 'Legal Reasoning from the Top Down and from the Bottom Up: The Question of Unenumerated Constitutional Rights' (1992) 59 U Chi L Rev 433 (although seeing a particular role for judicial intuition rather than explicit theorising); R Posner, 'Pragmatic Adjudication' (1996) 18 Cardozo L Rev l; and K Mason, 'What Is Wrong with 'Top-Down Legal Reasoning?' (2004) 78 ALJ 574.

8 CLindblom, "The Science of "Muddling Through"' (1959) 19 PAR 79.

9 Ibid 81-2. 
agreed set of values, objectives, and constraints, and an agreed ranking of these values, objectives and constraints, their marginal values in actual choice situations would be impossible to formulate.

Unable consequently to formulate the relevant values first and then choose among policies to achieve them, administrators must choose directly among alternative policies that offer different marginal combinations of values. Somewhat paradoxically, the only practicable way to disclose one's relevant marginal values even to oneself is to describe the policy one chooses to achieve them. Except roughly and vaguely, I know of no way to describe - or even to understand - what my relative evaluations are for, say, freedom and security ... in government decisions ... than to describe my preferences among specific policy choices that might be made between the alternatives in each of the pairs.

Historically, it may be argued, such styles of reasoning, which seek to provide 'practical measures for cooperative social life', have much to do with the common law. ${ }^{10}$ But does this have to change when the law comes under pressure to consider and evaluate human values in a more direct fashion as, for instance, with the new discourse of rights including rights to privacy and free speech? In this essay, I argue that the law has responded effectively to new demands for protection of privacy. And if judges have found it difficult to deal with rights-based reasoning it is not because the common law cannot accommodate rights - indeed there is a tradition in the law of talking about privacy as 'a right'. ${ }^{11}$ Rather, the difficulty stems from an initial deference to Kantian moral philosophy as the assumed only philosophy of rights. Yet even this may be changing in the latest cases which seem to be coming around to the idea that laws attuned to rights of privacy and free speech still have to accommodate the messiness of the self.

\section{B. Law's incrementalism}

In Attorney-General v Guardian Newspapers Ltd (No 2), ${ }^{12}$ Lord Goff provides a classic example of how a recognized form of action, in this case

10 T Grey, 'Freestanding Legal Pragmatism' (1996) 18 Cardozo L Rev 1, 42. See also

T Cotter, 'Legal Pragmatism and the Law and Economics Movement' (1996) 84 Geo

L) 2074 and G Hadfield 'The Second Wave of Law and Economics: Learning to Surf' in $M$ Richardson and G Hadfield (eds), The Second Wave of Law and Economics (Federation Press, Sydney 1999) 50.

11 For instance, there are references to the 'right' to privacy in the ancient case of Prince Albert $v$ Strange (1849) $1 \mathrm{H} \&$ Tw 1, 47 ER 1302 ('Prince Albert $v$ Strange'). And see $M$ Richardson and L Hitchens, 'Celebrity Privacy and Benefits of Simple History' in A Kenyon and M Richardson (eds), New Dimensions in Privacy Law: International and Comparative Perspectives (Cambridge University Press, Cambridge 2006) 250.

12 [1990] 1 AC 109 ('Spycatcher'). 
breach of confidence, may be developed to deal with new demands for privacy protection. As the doctrine is elaborated: ${ }^{13}$

I start with the broad general principle (which I do not intend in any way to be definitive) that a duty of confidence arises when confidential information comes to the knowledge of a person (the confidant) in circumstances where he has notice, or is held to have agreed, that the information is confidential, with the effect that it would be just in all the circumstances that he should be precluded from disclosing the information to others ...

I realise that, in the vast majority of cases, in particular those concerned with trade secrets, the duty of confidence will arise from a transaction or relationship between the parties ... But it is well settled that a duty of confidence may arise in equity independently of such cases; and I have expressed the circumstances in which the duty arises in broad terms, not merely to embrace those cases where a third party receives information from a person who is under a duty of confidence in respect of it, knowing that it has been disclosed by that person to him in breach of his duty of confidence, but also to include certain situations, beloved of law teachers - where an obviously confidential document is wafted by an electric fan out of a window into a crowded street, or where an obviously confidential document, such as a private diary, is dropped in a public place, and is then picked up by a passer-by ...

To this broad general principle, there are three limiting principles to which I wish to refer. The first limiting principle (which is rather an expression of the scope of the duty) ... is that the principle of confidentiality only applies to information to the extent that it is confidential. In particular, once it has entered what is usually called the public domain (which means no more than that the information in question is so generally accessible that, in all the circumstances, it cannot be regarded as confidential) then, as a general rule, the principle of confidentiality can have no application to it ...

The second limiting principle is that the duty of confidence applies neither to useless information, nor to trivia. There is no need for me to develop this point.

The third limiting principle is of far greater importance. It is that, although the basis of the law's protection of confidence is that there is a public interest that confidences should be preserved and protected by the law, nevertheless that public interest may be outweighed by some other countervailing public interest which favours disclosure ... It is this limiting principle which may require a court to carry out a balancing operation, weighing the public interest in maintaining confidence against a countervailing public interest favouring disclosure. 
A remarkable feature of the above passage is the subtle way in which Lord Goff, writing in 1988, moves to re-establish breach of confidence as a privacy doctrine in line with the great nineteenth-century case of Prince Albert $v$ Strange (cited in argument),${ }^{14}$ and away from the (by 1988) common understanding of breach of confidence as mainly about commercial and, to some extent, government secrets but only marginally of relevance to privacy. Thus, the particular examples used, of a confidential document wafted out a window or a private diary dropped in a street, actually had little bearing on the case before the House of Lords, being a government secrets case about the publication in several leading newspapers of extracts from the book Spycatcher written by a former British spy. ${ }^{15}$ It is clear from these examples - and also from Lord Goff's more general language of 'notice' of confidence as the basis of liability - that breach of confidence is being recast in the passage to take on a broader operation than previously had been supposed, in order to deal with the diversity of modern scenarios involving clashes between privacy and the media. But this is still bottom-up reasoning for, in essence, Lord Goff offers a pragmatic result-oriented reframing of the law which only marginally transcends traditional boundaries and is designed with actual, real-life, cases in mind.

What particular cases might Lord Goff have had in mind? One certainly would have been the notorious 1984 case of Francome $v$ Mirror Group $L t d,{ }^{16}$ where a well-known jockey and his wife objected to the Daily Mirror's publication of information about alleged breaches of racing rules obtained through a secret, illegal home telephone tap. The difficulty for the Court of Appeal was that when the case came to be decided it was widely assumed that breach of confidence was founded on a relationship of confidence between a confider and confidant. A relationship was posited as at least 'normally' required by Megarry J in an influential decision in Coco v AN Clark (Engineers) Ltd ${ }^{17}$ in 1969. Further, in 1979, in Malone v Metropolitan Police Commissioner, ${ }^{18}$ Megarry VC had held that in the absence of a relationship the claimant had no basis for objection to the police secretly tapping his telephone (there pursuant to a warrant), adding that people should be careful what they say in their gardens or on

\footnotetext{
${ }^{14}$ See $\mathrm{n} 11$.

15 PWright with P Greengrass, Spycatcher: The Candid Autobiography of a Senior Intelligence Officer (William Heinemann Australia, Melbourne 1987).

16 [1984] 2 All ER 408 ('Francome'). ${ }^{17}$ [1969] RPC 41, 47-48 (Megarry J).

18 [1979] Ch 344 (Megarry VC) ('Malone v Metropolitan Police Commissioner').
} 
public transport if they want to avoid being overheard, for the doctrine would not assist them. However, in Malone $v$ United Kingdom, ${ }^{19}$ the United Kingdom was found to have failed in its obligation to give legal support to the right to privacy enshrined in Article 8 of the European Convention on Human Rights. ${ }^{20}$ So in Francome the decision in Malone $\checkmark$ Metropolitan Police Commissioner was distinguished as concerned with a lawful telephone tap. Some commentators construed this to mean that only in cases of otherwise unlawful conduct may breach of confidence extend outside relationships of confidence, ${ }^{21}$ a position still incidentally giving a great deal of leeway to the media. But in Spycatcher Lord Goff brought surreptitious and other improper obtaining within the ambit of breach of confidence by the simple method of analogizing the liability of the person who obtains information with that of a third-party beneficiary of another's breach, which had long been based on notice.

Now it is conventional wisdom that surreptitious or improper obtaining may give rise to breach of confidence. This was not immediately apparent following Spycatcher. For instance, in Kaye $v$ Robertson, ${ }^{22}$ in 1990, Gordon Kaye (star of the 'Allo 'Allo! television series), suffering a serious brain injury after a car accident, found his hospital room invaded by a reporter and photographer who 'interviewed' him and took his photograph for The Sunday Sport. Breach of confidence was not argued and the Court of Appeal seemed unable to address the situation in terms of available legal protection of privacy. There were calls for a statutory privacy action, ${ }^{23}$ although they came to nothing. However, just over a decade later in Lenah, Gleeson CJ referred to Lord Goff in Spycatcher as high authority

19 (1985) 7 EHRR 14. Although the case predated the incorporation of the European Convention into domesticlaw by some fifteen years, the United Kingdomas a Convention signatory which also ratified the Convention was still accountable in the European Court of Human Rights for the failure of its institutions to ensure that the rights were complied with (and individual petitions to that Court were permitted from 1966); see, for a useful history, R Kerridge, 'Incorporation of the European Convention on Human Rights into United Kingdom Domestic Law' in MFurmston, R Kerridge and BE Sufrin, The Effect on English Domestic Law of Membership of the European Communities (Martinus Nijhoff, London 1983) 247, 247-48.

${ }^{20}$ Convention for the Protection of Human Rights and Fundamental Freedoms, Council of Europe (European Convention on Human Rights) (ECHR) 1950.

21 See for instance, G Wei, 'Surreptitious Takings of Confidential Information' (1992) 12 LS 302.

22 [1991] FSR 62.

${ }^{23}$ See ibid 66 (Glidewell LJ, Bingham and Legatt LJ concurring). Nor was this the first failed attempt to promote statutory reform of the law of confidence: see M Bryan, 'The Law Commission Report on Breach of Confidence: Not in the Public Interest?' [1982] PL 188. 
that breach of confidence is not restricted to relationships of confidence and thus is able to serve privacy interests in a broad fashion. ${ }^{24}$ Indeed, in Lenah, Gleeson CJ observed that had the information of the Tasmanian abattoir's operations (secretly recorded by animal rights activists then handed over for public broadcast) been private and confidential, breach of confidence would have been adequate to cover the case. ${ }^{25}$ Similarly, in its 2004 decision in Campbell v MGN Ltd, ${ }^{26}$ the House of Lords agreed that the Mirror could be found liable for breach of confidence as a result of its conduct in publishing surreptitiously snapped photographs of Naomi Campbell leaving a Narcotics Anonymous meeting. Lord Goff in Spycatcher was again relied on as clear authority for no relationship being needed. And in Douglas v Hello! Ltd (No 3), ${ }^{27}$ in 2006, the Court of Appeal accepted that Hello! was liable for breach of confidence for publishing surreptitiously snapped photographs of Michael Douglas and Catherine Zeta Jones' private wedding, a position not questioned when that case came before the House of Lords. ${ }^{28}$ In 1988 Lord Goff may have been seen as taking a radical and contentious step in opening up breach of confidence beyond relationships of confidence - although there were several older authorities which could be drawn on in support, as Gleeson CJ noted in Lenah. ${ }^{29}$ But in the twenty-first century, the position advocated by Lord Goff in Spycatcher is accepted as sound authority, with little acknowledgment that there was doubt even a decade ago.

\section{Thresholds versus balances}

Another feature of incremental reasoning nicely illustrated by Lord Goff's repositioning of breach of confidence as a privacy doctrine in Spycatcher is the emphasis given in the third limiting principle to 'balancing' public interests in maintaining confidentiality and facilitating public

${ }^{24}$ Lenah(n 5) [34]-[36] (Gleeson CJ), referringalso to the Australian case of Commonwealth of Australia v John Fairfax er Sons Ltd (1980) 147 CLR 39 ('John Fairfax') where, citing the old case of Lord Ashburton $v$ Pape [1913] 2 Ch 469, Mason J used language of information 'improperly or surreptitiously obtained' to frame the doctrine's scope.

${ }^{25}$ Lenah (n 5) [39]. As Gleeson CJ also recorded, in that case it was conceded on behalf of the claimant that the information was not confidential: [30] and further at [25].

${ }^{26}$ [2004] UKHL 22, [2004] 2 AC 457 ('Campbell').

27 [2005] EWCA Civ 595, [2006] QB 125 ('Douglas v Hello! Ltd').

${ }^{28}$ See OBG Ltd v Allan [2007] UKHL 21, [2008] 1 AC 1 (where OK!'s appeal from Douglas v Hello! Ltd was considered along with two other 'economic tort' appeals).

29 Seen 24 and further MRichardson, 'Breach of Confidence, Surreptitiouslyor Accidentally Obtained Information and Privacy: 'Theory Versus Law' (1994) 19 MULR 673. 
disclosure..$^{30}$ Even at the time of Spycatcher the position that there must be a public interest defence which allows for a weighing of interests was largely accepted as part of the common law doctrine. ${ }^{31}$ In 'The Science of "Muddling Through" Lindblom foreshadowed that for policy-makers difficult social choices involving significant and sometimes conflicting values may be best resolved through a process of determining 'preferences among specific policy choices'. ${ }^{32}$ The approach is actively encouraged by a limiting principle which invites judges to decide on a case-by-case basis precisely where - among those positions advocated by the parties respectively - the 'balance' of public interests should lie between, say, privacy and free speech. Nor is the principle's importance belied by the other limiting principle posited by Lord Goff, that 'the duty of confidence applies neither to useless information, nor to trivia'. ${ }^{33}$ For although at face value this qualification might suggest that courts should first consider whether the privacy value is sufficiently important in a particular case to be worth protecting even before moving to a second step of balancing between privacy and free speech, in practice the cases Lord Goff might have had in mind, writing in 1988, were few and far between.

Perhaps the most obvious scenario comes from Church of Scientology $v$ Kaufman, ${ }^{34}$ decided in 1972, where Goff J relied on triviality as a reason to deny an interlocutory injunction to the Church, which was seeking to stop publication of a book written by a disillusioned former adherent criticizing its teachings and methods. The subject matter was declared not worth protecting as being 'pernicious nonsense' and 'trivial tittle-tattle'. ${ }^{35}$ It may be wondered whether the 'pernicious nonsense' label was more appropriate

31 Certain judges in Australia, however, have maintained the traditional view that there is no public interest defence, as such, to breach of confidence although in accordance with the old case of Gartside v Outram (1856) 26 LJ Ch 378, 'iniquity' is not protected: see for instance, Corrs Pavey Whiting \& Byrne $v$ Collector of Customs (Vic) (1987) 14 FCR 434, 451-6 (Gummow J), and further Smith Kline \& French Laboratories (Aust) Ltd $v$ Secretary, Department of Community Services and Health (1990) 22 FCR 73, 110-11 (Gummow J); although contrast John Fairfax (n 24) 57 (Mason J) and Kirby P in the Australian Spycatcher case - Attorney-General (UK) v Heinemann Publishers Australia Pty Ltd (1987) 10 NSWLR 86, 170-1. In Lenah (n 5) [35], Gleeson CJ took for granted that the broader defence applied, noting also the relevance of the Australian implied constitutional freedom of political communication.

32 Lindblom (n 8) 81-2. See also presciently Bryan (n 23) 189, noting that despite the uncertainty of a defence that invokes a broad balancing of interests, "[i]t would hardly be sensible, even if it were possible, to elaborate the exact circumstances in which confidential information could be disclosed'.

33 Spycatcher (n 12) 282 (and see text to n 13). $\quad{ }^{34}$ [1973] RPC 627. ${ }^{35}$ Ibid 627. 
than triviality to critique the Church's claims that its relations with its adherents were private and were founded on a trust which now stood to be breached by the former adherent. Was this not rather a case of privacy and trust having questionable value for a claimant whose concern was to stifle public debate - conduct which today might be called an 'abuse of rights'? ${ }^{36}$ Be that as it may, there would seem to be a better basis still on which to deny the injunction. As Lord Denning MR noted in Hubbard $v$ Vosper $^{37}$ in 1971, another case involving the Church of Scientology (as well as its founder) seeking to prevent publication of a book written by a former adherent, the public interest defence to any breach of confidence claim would likely succeed if the case went to trial. Therefore, it may be questioned whether the claimant had met the proper standards for the award of an interlocutory injunction - a remedy that 'is so useful that it should be kept flexible and discretionary'. ${ }^{38}$ While there may have been some debate in 1971 as to how far courts should go in assessing substantive defences at the interlocutory stage, the proposition that a court asked to grant a prior restraint should deal with substantive issues (including available defences) as best it can on the available evidence and arguments at the interlocutory stage is now well accepted as the appropriate approach to cases which raise concerns about free speech. ${ }^{39}$

On the other hand, some might characterize as trivial the information in Woodward $v$ Hutchins, ${ }^{40}$ a 1977 case where pop stars Tom Jones, Engelbert Humperdinck, Gilbert O'Sullivan and Gordon Mills sought to stop publication of some articles revealing 'secrets' about the group's personal conduct and behaviour in the Daily Mirror. The irony of the

${ }^{36}$ Now such conduct, being aimed at the destruction of freedom of speech (itself a right identified by Article 10), might be considered an abuse of the Article 8 right to privacy under Article 17 of the ECHR. See also H MacQueen and D Brodie, 'Private Rights, Private Law and the Private Domain' in A Boyle and others(eds), Human Rights and Scots Law (Hart Publishing, Oxford 2002) 141, 151 (fn 50 especially).

37 [1972] 2 QB 84.

38 Ibid 95-7. The other judges, Megaw LJ and Stephenson LJ, concurred. For good measure, Megaw LJ added that the injunction should also be denied on the basis of unclean hands, there being strong evidence that 'the plaintiffs are or have been protecting their secrets by deplorable means' (at 101). Stephenson LJ 'entirely agree[d]' and (rather less plausibly) suggested that damages would be adequate in any event (at 101).

39 See for instance, Cream Holdings Ltd $v$ Banerjee [2005] 1 AC 103. The House of Lords decision there was premised on the language of s 12(3) of the Human Rights Act 1998 (UK), but for a similar approach to interlocutory injunctions and prior restraints developing in Australia, see Australian Broadcasting Corporation v O'Neill (2006) 227 CLR 57.

40 [1977] 1 WLR 760. 
situation was that a former agent, employed to create a desirable public image for the celebrities by selectively channelling their private information through the press, was doing the telling. As Lord Denning MR noted, 'this pop group sought publicity' and their agent's function was to 'produce' this 'favourable image, not only of their public lives but of their private lives also'. ${ }^{41}$ Again, however, the triviality characterization is problematic, for the information the Daily Mirror sought to publish and for which it had 'no doubt provided considerable reward' ${ }^{42}$ was worth a great deal to it, something to readers, and enough to the claimants to take legal steps to prevent publication. In any event, Lord Denning had another reason to deny the injunction, being the 'public interest' in correcting a false image by disclosing 'the truth'. ${ }^{43}$ There is some attraction in the idea that where an incomplete story is being presented through selective publication of personal information the claimant's interest in maintaining the myth should be discounted vis-à-vis the public's interest in knowing the truth on the other side. ${ }^{44}$ However, the suggestion here again was that the better way to deal with the limited value to be found in offering legal protection to confidentiality in these circumstances was by considering this alongside the value to be found in publication.

The impression that triviality per se was only a minor basis, at best, for denying breach of confidence's protection by the late 1980s is confirmed by other cases where triviality (in the sense of not sufficiently serious or otherwise worthy of protection) might have been invoked. For instance, the fact that the Duke of Argyll proposed to reveal marriage secrets of a domesticnature to The People did not prevent an injunction being granted in the 1967 case of Duchess of Argyll v Duke of Argyll,45 at the instance of his former wife. Nor in Stephens $v$ Avery ${ }^{46}$ handed down six months before Spycatcher, was the court prepared to strike out a breach of confidence claim against, inter alia, the Mail on Sunday for its story leaked by a former friend that Mrs Stephens was the secret lover of a woman who was murdered by her husband. It was argued that the claim was 'frivolous

${ }^{41}$ Ibid $763 .{ }^{42}$ Ibid. ${ }^{43}$ Ibid.

${ }^{44}$ Such reasoning lies at the heart of certain media and cultural studies scholarly critiques of celebrity claims of privacy (construing these as serving the interests of celebrities, their agents and promoters and compliant media outlets in 'strategically regulating' public understandings of their identities by selectively filtering personal information). These commentators may well take the reasoning considerably further than most judges: see, for instance, A Kenyon and E Milne, 'Images of Celebrity: Publicity, Privacy, Law' (2005) 10 MALR 311, 314 especially (and references noted there).

45 [1967] Ch 302 ('Argyll v Argyll'). ${ }^{46}$ [1988] Ch 449 ('Stephens v Avery'). 
or vexatious' but Sir Nicholas Browne-Wilkinson VC responded that 'I have the greatest doubt whether wholesale revelations of the sexual conduct of an individual can properly be described as 'trivial tittletattle'. ${ }^{47}$ So what was left to triviality by the time Lord Goff came to view it in Spycatcher? Bearing in mind the above cases it would seem not much. As Lord Goff said, once the threshold of confidentiality and notice is established (with its own standard of reasonable knowledge), ${ }^{48}$ the 'far more greatly important' limiting principle is balancing public interests. Thus, notwithstanding the reference to triviality posing a limitation for breach of confidence, Lord Goff accepted that in a very large majority of cases a decision as between values of confidentiality (or privacy) and free speech should be reached through the decisionmaking process that Lindblom ascribes to 'muddling through' - choosing directly among alternative policies that offer different marginal combinations of values.

Indeed, the same seems now to have been accepted by courts coming after, notwithstanding the new discourse of privacy as a 'right'. In the immediate wake of the Human Rights Act, bringing the ECHR with its rights to privacy and free speech into UK law, there was some suggestion that a rigorous threshold should be met before the right to privacy could be invoked in support of a breach of confidence claim. In Lenah, Gleeson CJ suggested that whether 'disclosure or observation of information or conduct would be highly offensive to a reasonable person of ordinary sensibilities' was 'in many circu mstances a useful practical test of what is private. ${ }^{49}$ And the Court of Appeal in Campbell adopted and relied on an offensiveness threshold to deny Campbell's claim for breach of confidence. ${ }^{50}$ But the House of Lords said a claimant need establish only a 'reasonable expectation' of privacy, judged from his or her perspective, and where free speech was also in issue the better course was to consider whether the reasonable expectation of privacy was outweighed by the public interest in free speech ${ }^{51}$ - identifying this with the (by then)

47 Ibid 454.

48 And see Spycatcher (n 12) 281 (Lord Goff), leaving open the extent to which notice may go beyond actual knowledge but adding that it must at least include circumstances where 'the confidant has deliberately closed his eyes to the obvious'.

49 Lenah (n 5) [42] (Gleeson CJ). ${ }^{50}$ Campbell (n 26).

51 As allowed for in Articles 8 and 10, which reference each other (in Articles 8(2) and 10(2)): see Campbell (n 26) [14]-[22] (Lord Nicholls), [46]-[56] (Lord Hoffmann, although without using the language of 'reasonable expectation' as such), [85]-[86] (Lord Hope), [132]-[136] (Lady Hale), [165]-[167] (Lord Carswell). 
traditional approach of Lord Goff in Spycatcher. ${ }^{52}$ Thus the Court of Appeal was 'wrong' to adopt a high offensiveness test which led it to hold that Campbell's treatment by Narcotics Anonymous could not be protected without 'balancing the competing Convention rights', Lord Hope said. ${ }^{53}$ And the majority found that on balance Campbell prevailed with her argument that the information was sensitive for a recovering addict (even if she could not complain about disclosure of her drug addiction, given she had publicly lied about it) and that the use of photographs especially was unnecessarily intrusive. Her privacy claim may have been rather weak but it was hard to see a stronger free speech argument on the other side. Similarly, the Court of Appeal added in Douglas v Hello! Ltd, ${ }^{54}$ it was wrong for the Court at the interlocutory stage to deny the Douglases an injunction against Hello!'s publication on the basis that their privacy interest was merely 'residual' once they sold the wedding rights to $O K ! .^{55}$ They had a genuine privacy interest in deciding what pictures should be published and it was likely they would have succeeded in their breach of confidence action at trial taking into account the limited public interest on Hello!'s side. ${ }^{56}$

\section{Incomplete theorizing}

Incomplete theorizing is also a feature of incrementalism, according to Lindblom. This is evident in Spycatcher where Lord Goff talks of balancing public interests in privacy and free speech, suggesting a vaguely utilitarian calculus but without any extended discussion of the utilitarian reasons why privacy and free speech may be important and how these interests may be reconciled. That, at least, might seem to have changed in the wake of the Human Rights Act. Almost immediately following the Act, judges in the United Kingdom and even Australia began to talk about the right to privacy as a matter of human dignity and autonomy. ${ }^{57}$ And, if references to Samuel Warren and Louis Brandeis' classic American article on 'The Right to Privacy' are anything to go by,

52 In the discussions above, Lord Nicholls, Lord Hoffmann and Lord Hope explicitly referred to Lord Goff in Spycatcher (and Lady Hale and Lord Carswell also agreed in general terms with Lord Hope).

${ }_{53}$ Campbell (n 26) [99]. ${ }^{54}$ Douglas v Hello! Ltd (n 27).

s5 Douglas v Hello! Ltd [2001] QB 967, especially 1006-7 (Sedley LJ).

56 Douglas v Hello! Ltd (n 27) [253]-[258].

57 See for instance, Douglas v Hello! Ltd [2001] QB 967, 999-1001 (Sedley LJ); Lenah (n 5) [43] (Gleeson CJ), [125]-[126] (Gummow and Hayne JJ). 
privacy was being reconceived as a matter of 'inviolate personality'58 suggesting a Kantian principle of treating human beings as ends in themselves rather than sacrificeable for the greater utilitarian good..$^{59}$ No wonder judges looked to establishing thresholds to be met before the inviolate right of personality could be invoked. A Kantian approach insists that, as Williams says, 'moral obligations ... cannot conflict, ultimately, really, or at the end of the line', moral obligations being 'inescapable'. ${ }^{60}$ However, with Campbell, courts seem to have reverted to a more utilitarian idea of privacy as a value whose importance in a particular case may well only be finally worked out in the balance with free speech and other public interests. Yet, intriguingly, they continue to use the language of dignity and autonomy. So, according to Lord Hoffmann in Campbell: ${ }^{61}$

What human rights law has done is to identify private information as something worth protecting as an aspect of human autonomy and dignity ... [Breach of confidence in the wake of the Human Rights Act] recognises that the incremental changes ... do not merely extend the duties arising traditionally from a relationship of trust and confidence to a wider range of people ... Instead of the cause of action being based upon the duty of good faith ..., it focuses on the protection of human autonomy and dignity - the right to control the dissemination of information about one's private life and the right to the esteem and respect of other people...

[Freedom of the press and the common law right of the individual to protect personal information] reflect important civilised values, but, as often happens, neither can be given effect in full measure without restricting the other. How are they to be reconciled in a particular case? There is in my view no question of automatic priority. Nor is there a presumption in favour of one rather than the other ... But when press freedom comes into conflict with another interest protected by law, the question is whether there is sufficient public interest in that particular publication to justify curtailment of the conflicting right.

Is this top-down reasoning? I suggest it provides yet another example of incomplete theorizing, consistent with Lord Hoffmann's language of 'incremental change'. In Campbell, it seems that the right to privacy is tacitly being absorbed into a liberal-utilitarian conception of privacy. Scholars may argue that dignity here has become synonymous with

58 S Warren and L Brandeis, 'The Right to Privacy' (1890) 4 Harv L Rev 193.

59 I Kant, 'Groundwork of the Metaphysics of Morals' (1785) reprinted in HJ Paton (trs), The Moral Law (Hutchinson, London 1948).

60 Williams (n 3) 176-7. ${ }^{61}$ Campbell (n 26) [50]-[55] (Lord Hoffmann). 
individuality, human flourishing and through.that social progress ${ }^{62}-$ or rather it is being reabsorbed into a utilitarian treatment of privacy for there are traces of the reasoning also in the ancient case of Prince Albert $v$ Strange. ${ }^{63}$ It may also be posited that, viewed in such a utilitarian fashion, privacy can never be given automatic priority over other social interests - especially free speech which also has utilitarian value lying in its expressive power, its contribution to democratic debate, and its capacity to generate truth. ${ }^{64}$ If so, much can be found in common with John Stuart Mill's understanding of a 'right' as simply a shorthand expression for talking about an interest which is regarded so highly that 'ought and should grow into must and recognised indispensability becomes a moral necessity', but which may yet be out weighed in a fuller and final assessment of social interests. ${ }^{65}$ Much of this positing is merely surmise, however, for little is said about the nature of rights, let alone the right to privacy, in the cases. There was no reference made to Mill, for instance, in Campbell. Rather, in the traditional fashion of common law, as Mill might have said, judges continue to operate chiefly 'by stealth'.66

There is a further implication to the incrementalism being displayed here. Perhaps privacy and free speech are themselves evolving concepts like everything else in the common law, their evolution further catalyzed by their constantly shifting relations inter se. It may be that, at its simplest, privacy entails a right to be 'let alone', not to express oneself, as Warren and Brandeis argued in $1890 .{ }^{67} \mathrm{But}$ in actual cases, privacy and expression often go hand in hand, as Eric Barendt points out in an important recent essay. ${ }^{68}$ And the multiple and various ways in which they may do so are still being discovered. Already we know that privacy encompasses not sharing deeply personal information except with trusted family or

62 In other words, that dignity has become part of, rather than distinct from, the broader liberal-utilitarian rationale for privacy protection discussed in M Richardson, 'Whither Breach of Confidence: A Right of Privacy for Australia?' (2002) 26 MULR 381.

${ }^{63}$ See Richardson and Hitchens (n 11) 262-3.

${ }^{64}$ See John Stuart Mill, 'On Liberty' (1859) reprinted in Mary Warnock (ed), On Liberty: Essay on Bentham (Collins, London 1962) ch 2; and E Barendt, Freedom of Speech (2nd edn Oxford University Press, Oxford 2005) ch 1.

65 John Stuart Mill, Utilitarianism (1861/1863) reprinted in Warnock (n 64) 310 and throughout. And see also D Lyons, Rights, Welfare and Mill's Moral Theory (Oxford University Press, New York 1994) ch 6.

${ }_{66}$ And see John Stuart Mill, 'Bentham' (1838) reprinted in War nock (n 64) 108.

67 War ren and Brandeis (n 58) 205.

${ }^{68}$ E Barendt, 'Privacy and Freedom of Speech' in Kenyon and Richardson (n 11) 11. 
friends - as in Argyll v Argyll and Stephens $v$ Avery. ${ }^{69}$ It also embraces not sharing deeply personal information except with a limited circle of people who are not family or close friends, as in Campbell - and more lately Mosley $v$ News Group Newspapers Ltd. ${ }^{70}$ There, damages were awarded for breach of confidence and privacy after the News of the World published a story on racing boss Max Mosley's participation in regular orgies involving the same secret group meeting in his neighbourhood, usually finishing with a cup of tea. ${ }^{71}$ It extends as well to a right to share significant intimate moments with a large group of family and friends as well as an even larger group of fans (but subject to limited terms), as in Douglas $v$ Hello! Ltd. And, with the subsequent decision in Murray $v$ Big Pictures (UK) $L t d,^{72}$ it potentially encompasses sharing even anodyne intimate moments with close family (and presumably friends) but not the public at large, since in that case the objection made in the name of Joanne Rowling's infant son was to photographs covertly taken of him going out to dinner with his family in Edinburgh. The Court of Appeal refused to strike out the claim (or to limit its reasoning to the protection of infants, although clearly that was a consideration), noting that latitude should be given to privacy claimants to make clear what they wish to have treated as private. ${ }^{73}$ In none of these cases do judges seem to wonder much why those concerned might choose to insist on privacy - they may not know themselves - except that it is obviously a choice they have made. In short, we seem to have reached a position where the common law of privacyconfidentiality accommodates the messiness of the self.

69 Similarly McKennitt v Ash [2006] EWCA Civ 778, [2008] QB 73 ('McKennitt v Ash'), another case of unwanted disclosures by a former friend, and the recent Australian case Giller $v$ Procopets [2008] VSCA 236 in the Victorian Court of Appeal, where in an action against a former partner it was accepted the sex scenes recorded were confidential to the parties' relationship and distressing to the claimant when circulated to her family, local community and employer (leave to appeal to the High Court was denied on 23 September 2009).

70 [2008] EWHC 1777 (QB) ('Mosley').

71 Mosley (son of Oswald Mosley) objected to a Nazislur as falsebut also made plain he would rather that his family had not had to know about the orgies - pointing out also that the damages award (being premised on publication) was not actually sufficient to address his privacy concerns: 'Orgy Story Took Mosley Dignity' BBC News (10 March 2009) <http:// news.bbc.co.uk/2/hi/uk_news/politics/7934438.stm>. See also G Phillipson, 'Max Mosley Goes to Strasbourg: Article 8, Claimant Notification and Interim Injunctions' (2009) $1 \mathrm{~J}$ Media Law 73.

72 [2008] EWCA Civ 446.

${ }^{73}$ Ibid [36] (emphasising the role of absent consent among other circumstances) and further [50]-[56]. 
Perhaps this is where the story should end. But there is still the question of the future. Will breach of confidence fall into obscurity as privacy takes over, as seems to be anticipated in some recent British cases? Breach of confidence is 'old fashioned', according to Eady J in Mosley, as distinguished from a ('new fashioned') privacy claim under Article 8. ${ }^{74}$ The reasoning presupposes that the language of privacy is superior to that of confidentiality, being more in touch with modern concerns. But I wonder whether even privacy may become an arcane concept as still more modern concerns arise. These can already be sensed in a number of cases that touch on the networked generation's desires to share personal information and reflections with large numbers of loosely defined friends, or potential friends, while still retaining someresidual control. ${ }^{75}$ So far courts have resisted suggestions that activities on the internet could be viewed as private, unless effective privacy settings are in place (and it seems that technology is as ineffective in the virtual world as in the real world in supporting privacy, perhaps even more so). Blogging is a 'public activity', said Eady J in the recent Night Jack case ${ }^{76}$ in response to a blogger's claims of breach of confidence and/or privacy on finding his anonymity pierced by a journalist using mostly internet sources to piece together his identity. Equally, conversations on Facebook (one of the sources) are in the public domain. ${ }^{77}$ So there was no need to consider whether The Times's exposé served any public interest that outweighed the claimant's interest in maintaining control over how much of himself he cared to present to his audience. The language of privacy may seem inadequate to capture what was being sought here. But, is any language perfect? Should we acknowledge what writers of fiction have long understood, the powerlessness of expression together with the obligation to express? ${ }^{78}$ If the common law is to keep up with fresh demands for legal protection, judges - like the rest of us - may have to live with the inadequacy of 'privacy' until something (slightly) better comes along.

${ }_{74}$ Mosley (n 70) [6] (Eady J) quoting from Buxton LJ in McKennitt v Ash (n 69) [8].

${ }^{75}$ For instance, Author of a Blog $v$ Times Newspapers Ltd [2009] EWHC 1358 ('Night Jack') and Moreno $v$ Hanford Sentinel, Inc, 172 Cal App 4th 1125 (2009).

${ }^{76}$ Night Jack (n 75) [33].

77 See [4.3] of the Claimant's Skeleton Argument (Hearing 4 June 2009). Thanks to Hugh Tomlinson (who represented the claimant, Richard Horton, in the case) for helpfully providing this information.

78 See Samuel Beckett's 'Three Dialogues with Georges Duthuit' (1949) reprinted in S Beckett, Proust: Three Dialogues with Georges Duthuit (J Calder, London 1965) 103. 


\section{University Library}

\section{- M M I N E R VA A gateway to Melbourne's research publications}

Minerva Access is the Institutional Repository of The University of Melbourne

Author/s:

Richardson, M

Title:

Towards legal pragmatism: Breach of confidence and the right to privacy

Date:

2010-01-01

Citation:

Richardson, M. (2010). Towards legal pragmatism: Breach of confidence and the right to privacy. Bant, E (Ed.). Harding, M (Ed.). Exploring Private Law, (1), pp.109-124. Cambridge University Press.

Persistent Link:

http://hdl.handle.net/11343/30226 